Sustainable Development and Planning X 509

\title{
TOURISM DEVELOPMENT OF THE CYCLADES ISLANDS: ECONOMIC, SOCIAL AND CARRYING CAPACITY ASSESSMENT AND CONSEQUENCES
}

\author{
DIMITRIS PROKOPIOU ${ }^{1}$, GEORGE MAVRIDOGLOU ${ }^{2}$, MICHAEL TOANOGLOU $^{3} \&$ BASIL TSELENTIS $^{1}$ \\ ${ }^{1}$ Department of Maritime Studies, University of Piraeus, Greece \\ ${ }^{2}$ Technological Educational Institute of Peloponnesus, Greece \\ ${ }^{3}$ Woosong University, South Korea
}

\begin{abstract}
The tourist industry is one of the most important economic activities in Greece. The country receives over 32 million visitors per year. Greece has enjoyed increasing numbers of people and revenues from tourism, due to the unique environments that are both natural and man-made that make it a high-profile tourist destination; however, it is already clear that uncontrolled growth of the industry may bring serious environmental and social problems, leading to a decline in the quality of tourist product and services provided. According to the triple bottom line (TBL) philosophy developed by Elkington (1998), sustainable tourist development must be balanced at the same time with economic, social and environmental aims, from a microeconomic point of view, as tools to measure environmental impact. The Prokopiou-Tselentis model is an integrated assessment system for environmental management and impact estimation of a tourism destination. In this paper, we propose the implementation of the Prokopiou-Tselentis model as the economic, social and tourism situation demands data to estimate the development of tourism and its impact on the Greek islands of Cyclades.

Keywords: Cyclades, environmental management, Greece, sustainable tourism, tourism carrying capacity, tourism.
\end{abstract}

\section{INTRODUCTION}

Greece depends heavily on the tourist trade, as tourism is the main economic activity in Greece. The issue for long-term viable development in the Greek islands is to find a creative and hopeful perspective, through carrying capacity assessment indicators. Sustainable development has a quantification procedure with a specialized instrument, which constitutes a vital element for assessing the environmental conditions of Greek destinations; as tourism is a blend of ecological, social and economic sub-systems [1]. For that reason, an adapted amount of sustainable indicators are selected and a comprehensive prototype model for their use is created, aiming for reliable measurement of the selected parameters that are considered to be important for our region. We believe that using this approach, the local societies and stakeholders involved will be able to understand the size of their impact on the existing and mainly non-renewable resources, in order for Greece to proceed with strategic planning and terms of sustainability for future courses of development. The natural environment is crucial to the attractiveness of almost all travel destinations and recreation areas [2].

Coastal and marine areas are important recreational resources for both the local residents and tourists, who spend much time doing marine activities [3]. Coastal zone management is emerging as a major concern for governments [4]. Through this study and its results, the researcher will try to determine the destination's status, in order to improve tourism and suggest a plan that will help these islands to become more competitive and attractive as tourist destinations. Carrying capacity assessment has become an indispensable tool for formulating policy and strategies for managing the tourist industry worldwide [5]. Countries and regions with considerable natural and cultural resources look towards tourism as an aspect to consider when looking to stimulate their sustainable development activities [6]. 
The contribution of the tourism sector towards development needs to be clearly explained, to allow countries to invest well into promoting tourism. Tourism is considered as a development factor [7] and is probably the best example among human activities in which the links between environmental quality and economic prospects are evident [8]. The purpose of this study is to examine the current state of the islands of the Cyclades, by analysing the interactions between tourism and the environment, and by examining environmental indices [9].

\subsection{Cyclades islands}

The Cyclades is an island group in the Aegean Sea, one of Greece's most attractive destinations that are popular among both foreign and domestic visitors alike, especially during the summer period. Gorgeous sandy beaches, stunning local architecture in white and blue, and a rugged yet pristine landscape characterized by little white churches and windmills; coupled with an easy-going traditional lifestyle, marvellous cooking, folk music, and warm and hospitable people. A trip to the Cyclades is a lifetime experience.

The name "Cyclades" refers to the islands forming a circle (in English it means "circular islands") around the sacred island of Delos. According to the Greek mythology, Poseidon, God of the sea, was furious at the Cyclades nymphs and turned them into islands. The Cyclades are located in the south Aegean Sea and comprise about 200 islands. The major ones are: Amorgós, Anáfi, Ándros, Antíparos, Dēlos, Íos, Kéa, Kímōlos, Kýthnos, Mēlos, Mykonos, Náxos, Páros, Folégandros, Sérifos, Sífnos, Síkinos, Sýros, Tēnos, and Thēra or Santoríni. Most of the smaller islands are uninhabited. Ermoupolis, in Syros, is the capital and administrative centre of the former prefecture. The islands are peaks of a submerged mountainous terrain, with the exception of two volcanic islands, Milos and Santorini.

The climate is generally dry and mild. With the exception of Naxos' soil, which is very fertile, agricultural production includes: wine, fruit, wheat, olive oil and tobacco. The population of the Cyclades is mainly concentrated in Syros $(19,870)$, Naxos $(18,988)$, Thira $(13,960)$, Paros $(12,853)$, Andros (10,009), Mykonos $(9,320)$, and Tinos $(8,574)$. The remaining islands have populations that do not exceed 4,000 inhabitants. There is only one town with more than 10,000 thousand inhabitants: Ermoupolis, the Capital of the Cyclades, with a population of approximately 15,000 . Until late $60 \mathrm{~s}$, the inhabitants had been engaged mainly in agricultural, fishing and shipping pursuits. There was a large wave of migration, mainly to the urban centres of the country and mainly to Piraeus. The tourist boom began in the late 1960s and became a dominant activity in the $90 \mathrm{~s}$.

\subsection{Scope of the study}

Triple bottom line (TBL) philosophy, developed by Elkington [10], balances at the same time the economic, social and environmental aims from an economic point of view. The intersection of social, environmental, and economic performance, and the adoption of the right strategy could benefit the people and the planet, and at the same time provide results in providing long-term economic benefits. The economic bottom line contributes social equity and environmental conditions as a part of both strategy and planning (Elkington, [10]). The theory had been developed for enterprises, but we believe that its philosophy can be extended to small tourist areas, such as the Cyclades.

The attraction of tourists is not an autonomous activity of tourist units, but is directly related to the tourist policy of the island and also all the tourist market in the area. All of 
these can be considered as "shareholders" of the region's tourism industry. Under this point of view, sustainable tourism management doesn't only examine financial performance, but also the integration of environmental or social objectives that extend the economic dimension to the TBL philosophy.

The purpose of this research is to assess the environmental burden of tourism development in the Cyclades islands. Wanting to highlight the difficulty of dealing with the environmental burden, we looked at two other factors, the economic and social development that tourism has brought into these areas. Balancing these three dimensions is a challenge, both for central and local administrations, as well as for tour operators.

\section{METHODOLOGY}

In order to achieve our study objective, it was necessary to collect data on the economic effects of tourism development, as well as the social development of these areas in recent years. Measurement of the economic outcomes of tourism development results were obtained from the macroeconomic data of the region. The economic dimension can be measured by financial data provided by the Hellenic Statistical Authority and the Bank of Greece.

The second dimension was measured with less quantitative data and concerned the development and quality of life in the Cyclades. For the environmental dimension, we found a lot of models proposed in our bibliography, we will mention the contributions of LosanoOyola et al. [11], Hadjibiros et al. [12], Blancas et al. [13]. Also, Petrosillo et al. [14] suggests adopting suitable indicators for the environmental impact assessment. In our study, we used the Prokopiou Tselentis model. The proposed model is based on sixteen variables which take values from 0 to 100, and is based on the Navaro Jurado et al. [15] study and discussion for the methodology for carrying capacity for tourist destinations and for the creation of synthetic indicators, as applied to a coastal area.

The Prokopiou Tselentis model uses a set of 16 indicators to evaluate the environmental impact of tourism activities. The 16 variables can be divided in two groups. The main objective of the first group of variables is to rate environmental characteristics and infrastructure of the area. This group includes twelve out of sixteen variables (Table 1). The second group consists of four variables (Table 2). The model was presented by Prokopiou et al. [16] and used in a paper by the same author [17].

The score was derived from using questionnaires and qualitative indicators for each area. The data was selected from the 31 municipalities and communities in the Cyclades Islands. For the survey, questionnaires were sent to all these municipalities. We received responses from everyone, so this research can be considered a census. The questionnaire listed the municipalities' environmental infrastructure as well as their capabilities, natural resources and any nuisance from tourism development.

\section{RESULTS}

\subsection{Tourist development}

Tourism development in the Cyclades mainly began in 1980. In 1977, the islands with more than 5 hotels were: Andros (with 15 hotels), Ios (8 hotels), Milos (5 hotels), Mykonos (17 hotels), Naxos (18 hotels), Paros (20 hotels), Syros (14 hotels), Thira-Santorini (9 hotels) and Tinos (17 hotels). Massive tourism development in all of the Cyclades started after the $90 \mathrm{~s}$. 
Table 1: Environmental and infrastructure variables.

\begin{tabular}{|c|c|c|}
\hline Variable name & Description & Measurement \\
\hline V1 & Urban waste management & $0-100$ \\
\hline V2 & Legality of buildings & $0-100$ \\
\hline V3 & Protection of noise nuisance & $0-100$ \\
\hline V4 & Garbage management & $0-100$ \\
\hline V5 & Protection from pesticide use & $0-100$ \\
\hline V6 & Over-pumping of seawater & $0-100$ \\
\hline V7 & Sufficient quantity of water resources & $0-100$ \\
\hline V8 & Sufficient quality of drinking water & $0-100$ \\
\hline V9 & Exposure to forest fires & $0-100$ \\
\hline V10 & Land clearing & $0-100$ \\
\hline V11 & Landscape conservation & $0-100$ \\
\hline V12 & Adequacy of green areas & $0-100$ \\
\hline
\end{tabular}

Table 2: Environmental and infrastructure variables related to beds.

\begin{tabular}{|c|c|c|}
\hline Variable name & Description & Measurement \\
\hline V13 & Beds per kilometer of beach & $0-100$ \\
\hline V14 & Beds per square kilometer & $0-100$ \\
\hline V15 & Beds per inhabitant & $0-100$ \\
\hline V16 & Blue flags per kilometer of beach & $0-100$ \\
\hline
\end{tabular}

In 2005, the total hotel capacity in the Cyclades was 39,917 beds. Table 3 presents the current situation in accommodation facilities, hotels and apartments and the number of beds. In 12 years, the accommodation supply had increased by $20 \%$.

Table 4 shows the number of arrivals at Cyclades airports, both from abroad and from the rest of Greece. The two main getaways for foreign arrivals are the Mykonos and Santorini airports. Syros, Paros and Naxos islands have smaller airports and receive a limited number of international flights, mostly during the high season's three months. The results show that there is a significant increase in foreign visitors arriving, except in 2012, the year in the middle of economic crisis in Greece. The bottom half of Table 4 shows the increase in domestic arrivals by air. In Table 4, we are also able to identify the important role that airlines can play in tourism development, particularly on islands like Milos, Paros, Syros, and Naxos, which already have airports that, are currently used almost exclusively for domestic flights 
using small commercial aircraft. It should be noted that many foreign visitors are coming through Athens using a domestic flight, which means that their numbers include both international and domestic visitors. It must be also noted that except for a number of visitors that arrive by air in the Cyclades islands, a big number of tourists arrived from the ports of Piraeus and Rafina.

Table 3: Hotel capacity and rooms for rent in Cyclades islands in 2017. (Source: SETE.)

\begin{tabular}{|c|c|c|c|c|c|c|}
\hline \multicolumn{7}{|c|}{ Hotel capacity } \\
\hline & $5^{*}$ & $4 *$ & $3^{*}$ & $2^{*}$ & $1^{*}$ & Total \\
\hline Units & 146 & 289 & 346 & 628 & 225 & 1,634 \\
\hline Rooms & 92 & 193 & 223 & 371 & 137 & 1,016 \\
\hline Guest beds & 8,048 & 11,879 & 11,349 & 15,001 & 3,993 & 50,270 \\
\hline \multicolumn{7}{|c|}{ Rooms for rent } \\
\hline & $4 \mathrm{~K}$ & $3 \mathrm{~K}$ & $2 \mathrm{~K}$ & $1 \mathrm{~K}$ & & Total \\
\hline Units & 485 & 2,241 & 3,275 & 883 & & 6,884 \\
\hline Rooms & 903 & 4,312 & 6,378 & 1,731 & & 13,324 \\
\hline Guest beds & 7,959 & 27,271 & 31,622 & 6,993 & & 73,845 \\
\hline
\end{tabular}

Table 4: Arrivals in Cyclades island airports.

\begin{tabular}{|c|c|c|c|c|c|c|c|c|}
\hline & 2010 & 2011 & 2012 & 2013 & 2014 & 2015 & 2016 & 2017 \\
\hline \multicolumn{9}{|c|}{ FOREIGN } \\
\hline Mykonos & 111,136 & 130,974 & 140,131 & 177,540 & 247,126 & 275,812 & 301,842 & 346,057 \\
\hline Santorini & 181,746 & 202,139 & 200,271 & 244,449 & 310,416 & 356,443 & 389,817 & 431,183 \\
\hline TOTAL & 293,644 & 333,822 & 340,851 & 422,743 & 558,343 & 633,714 & 691,652 & 778,113 \\
\hline \multicolumn{9}{|c|}{ DOMESTIC } \\
\hline Mykonos & 100,212 & 106,293 & 106.254 & 110,431 & 138,521 & 153,916 & 189,961 & 231,251 \\
\hline Santorini & 161,552 & 173,493 & 166,723 & 185,372 & 252.221 & 361,521 & 433,592 & 488,101 \\
\hline Naxos & 10,112 & 11,562 & 9,982 & 10,066 & 14,305 & 19,474 & 16,537 & 26,671 \\
\hline Syros & 6,796 & 4,183 & 4,818 & 5,954 & 6,654 & 5,996 & 7,689 & 8,886 \\
\hline Paros & 20,532 & 22,205 & 20,417 & 21,475 & 24,259 & 27,218 & 37,872 & 74,167 \\
\hline Milos & 18,049 & 16,822 & 16,608 & 15,220 & 19,217 & 24,531 & 23,685 & 26,346 \\
\hline TOTAL & 317,261 & 334,563 & 324,865 & 348,523 & 455,187 & 592,707 & 709,344 & 855,421 \\
\hline
\end{tabular}


It is obvious that increased airport passenger arrivals (domestic and international) in the Cyclades had a higher rate of growth after 2014, when the sharing economy phenomenon and AirBnB in particular started to play an important role in the Greek tourism market. Thousands of properties on these islands are now on offer to foreign and domestic tourists for vacationing purposes, offering a cheaper, and for some more attractive, accommodation alternative.

\subsection{Economic and social assessments}

Tourism became the main economic activity in the Cyclades islands and the South Aegean. Especially in the years of Greece's economic crisis (2010-today), the economy of the region is heavily reliant on tourism. It must be mentioned that $15 \%$ of the country's total tourist revenue comes from tourists in the Cyclades area, and that tourism accounts about $70 \%$ of the GDP of the region. The main result is the increase in residents' income, so that the Cyclades is the region with the second largest per capita income in the country, standing over of 20,000 euros (Fig. 1).

More than 32,000 inhabitants work in the tourism sector. From 2010, those working in the tourism sector increased by 50\%. In 2017, employment in tourism accounted for more than $25 \%$ of the total work force in the region (Fig. 2). Apart from the inhabitants involved in tourism; however, many other professionals have been helped by tourism, as an example: small farmers and wine producers.

Moreover, the development of tourism and its positive impact in the Greek economy has led the central government to design and build infrastructures on these islands. A few

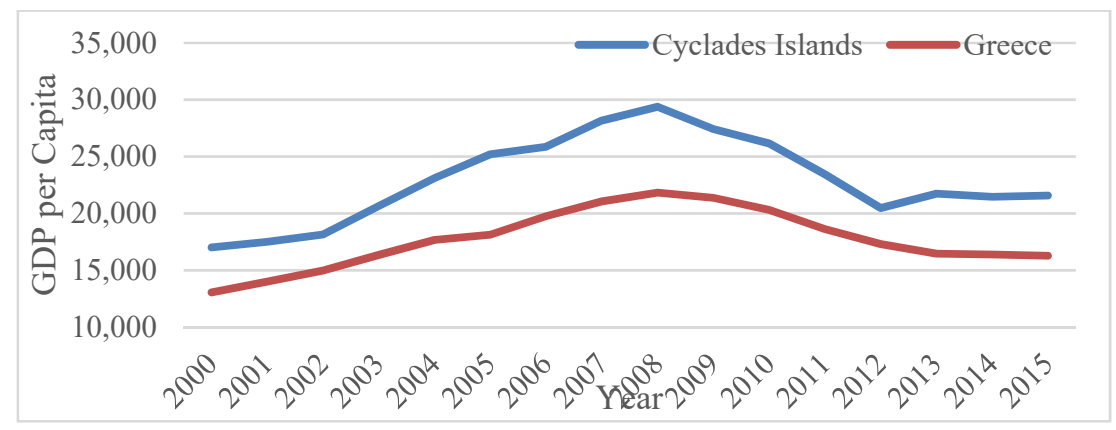

Figure 1: GDP per capita.

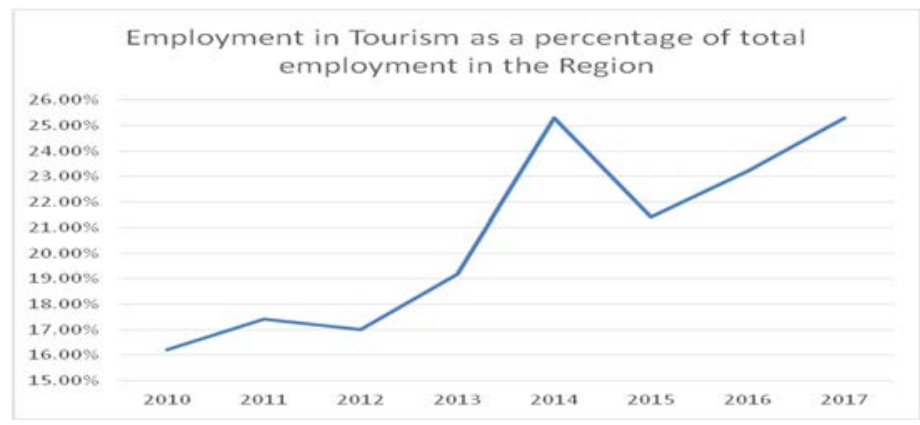

Figure 2: Employment in tourism. 
examples of this development include the improvement of transport and access to mainland Greece, expansion of the banking network, new medical centres and new desalination plants. The difficulties faced by residents 30 years ago, are now in the past. Cyclades has gone from a region of poor small farmers and fishermen, to become transformed into a region with wealth and development opportunities.

\subsection{Environmental assessment}

According to the above analysis, tourism has been a source of growth and prosperity for the island population. But questions remain: What are the limits of tourism development? What are the possibilities for tourist accommodation within the existing infrastructure? What are the impacts of tourism development on the environment?

Using the Prokopiou Tselentis model, we assessed the environmental dimensions of tourism development [16]. The results per island and indicator are presented in Tables $5-9$.

Table 5: Environmental indicators per island, for Syros, Amorgos, Andros, Thira and Thirasia.

\begin{tabular}{|c|c|c|c|c|c|c|c|c|c|c|}
\hline & \multicolumn{2}{|c|}{ SYROS } & \multicolumn{2}{c|}{ AMORGOS } & \multicolumn{2}{c|}{ ANDROS } & \multicolumn{2}{c|}{ THIRA (Santorini) } & \multicolumn{2}{|c|}{ THIRASIA } \\
\hline & Mean & StDev & Mean & StDev & Mean & StDev & Mean & StDev & Mean & StDev \\
\hline V1 & 40 & 52.9 & 0 & $*$ & 0 & 0 & 85 & 7.07 & 0 & $*$ \\
\hline V2 & 66.7 & 57.7 & 100 & $*$ & 100 & 0 & 25 & 35.4 & 0 & $*$ \\
\hline V3 & 86.67 & 11.55 & 100 & $*$ & 100 & 0 & 60 & 0 & 100 & $*$ \\
\hline V4 & 63.3 & 28.9 & 0 & $*$ & 26.7 & 46.2 & 80 & 0 & 80 & $*$ \\
\hline V5 & 33.3 & 57.7 & 100 & $*$ & 83.3 & 28.9 & 100 & 0 & 100 & $*$ \\
\hline V6 & 0 & 0 & 0 & $*$ & 83.3 & 28.9 & 0 & 0 & 100 & $*$ \\
\hline V7 & 50 & 50 & 0.7 & $*$ & 100 & 0 & 100 & 0 & 50 & $*$ \\
\hline V8 & 66.7 & 57.7 & 100 & $*$ & 100 & 0 & 100 & 0 & 100 & $*$ \\
\hline V9 & 100 & 0 & 100 & $*$ & 100 & $*$ & 100 & 0 & 100 & $*$ \\
\hline V10 & 100 & 0 & 100 & $*$ & 100 & 0 & 50 & 0 & 100 & $*$ \\
\hline V11 & 76.7 & 25.2 & 80 & $*$ & 76.7 & 25.2 & 50 & 0 & 100 & $*$ \\
\hline V12 & 33.3 & 57.7 & 100 & $*$ & 60 & 52.9 & 50 & 0 & 100 & $*$ \\
\hline V13 & 2052 & 2750 & 399.41 & $*$ & 196.4 & 129.3 & 518 & 484 & 22 & $*$ \\
\hline V14 & 125.4 & 124.1 & 196.4 & $*$ & 10.79 & 7.61 & 162.8 & 87.9 & 4.7317 & $*$ \\
\hline V15 & 0.45 & 0.274 & 1.8263 & $*$ & 0.467 & 0.481 & 643 & 908 & 0.15827 & $*$ \\
\hline V16 & 0.33 & 0.316 & 0 & $*$ & 0.0667 & 0.1155 & 0.08 & 0.1131 & 0 & $*$ \\
\hline
\end{tabular}


Table 6: Environmental indicators per island, for Ios, Kea, Kythnos, Milos and Mykonos.

\begin{tabular}{|c|c|c|c|c|c|c|c|c|c|c|}
\hline & \multicolumn{2}{|c|}{ IOS } & \multicolumn{2}{c|}{ KEA } & \multicolumn{2}{c|}{ KYTHNOS } & \multicolumn{2}{c|}{ MILOS } & \multicolumn{2}{c|}{ MYKONOS } \\
\hline & Mean & StDev & Mean & StDev & Mean & StDev & Mean & StDev & Mean & StDev \\
\hline V1 & 0 & $*$ & 50 & $*$ & 100 & $*$ & 0 & $*$ & 50 & $*$ \\
\hline V2 & 0 & $*$ & 50 & $*$ & 100 & $*$ & 0 & $*$ & 50 & $*$ \\
\hline V3 & 80 & $*$ & 80 & $*$ & 80 & $*$ & 80 & $*$ & 80 & $*$ \\
\hline V4 & 30 & $*$ & 0 & $*$ & 80 & $*$ & 0 & $*$ & 80 & $*$ \\
\hline V5 & 50 & $*$ & 100 & $*$ & 50 & $*$ & 0 & $*$ & 100 & $*$ \\
\hline V6 & 0 & $*$ & 0 & $*$ & 100 & $*$ & 100 & $*$ & 100 & $*$ \\
\hline V7 & 0 & $*$ & 100 & $*$ & 0 & $*$ & 100 & $*$ & 100 & $*$ \\
\hline V8 & 0 & $*$ & 100 & $*$ & 0 & $*$ & 100 & $*$ & 0 & $*$ \\
\hline V9 & 100 & $*$ & 100 & $*$ & 80 & $*$ & 100 & $*$ & 100 & $*$ \\
\hline V10 & 100 & $*$ & 100 & $*$ & 100 & $*$ & 100 & $*$ & 0 & $*$ \\
\hline V11 & 50 & $*$ & 20 & $*$ & 100 & $*$ & 30 & $*$ & 30 & $*$ \\
\hline V12 & 0 & $*$ & 0 & $*$ & 100 & $*$ & 0 & $*$ & 0 & $*$ \\
\hline V13 & 457.07 & $*$ & 102.39 & $*$ & 64.2 & $*$ & 214.29 & $*$ & 1837.5 & $*$ \\
\hline V14 & 40.12 & $*$ & 7.1908 & $*$ & 9.6979 & $*$ & 29.17 & $*$ & 221.41 & $*$ \\
\hline V15 & 2.3575 & $*$ & 0.38974 & $*$ & 0.59888 & $*$ & 0.92077 & $*$ & 2.0307 & $*$ \\
\hline V16 & 0.32 & $*$ & 0.11 & $*$ & 0 & $*$ & 0 & $*$ & 0.1 & $*$ \\
\hline
\end{tabular}

Table 7: Environmental indicators per island, for: Naxos, Paros, Serifos, Sifnos and Tinos.

\begin{tabular}{|l|l|l|l|l|l|l|l|l|l|l|l|}
\hline & \multicolumn{2}{l}{ NAXOS } & \multicolumn{2}{l}{ PAROS } & \multicolumn{2}{l|l}{ SERIFOS } & \multicolumn{2}{l|}{ SIFNOS } \\
\hline & Mean & StDev & Mean & StDev & Mean & StDev & Mean & StDev & Mean & \multicolumn{2}{l|}{ StDev } \\
\hline V1 & 77.5 & 24.7 & 70 & $*$ & 70 & $*$ & 12 & $*$ & 0 & 0 \\
\hline V2 & 65 & 21.2 & 0 & $*$ & 0 & $*$ & 80 & $*$ & 0 & 0 \\
\hline V3 & 80 & 28.3 & 60 & $*$ & 100 & $*$ & 100 & $*$ & 93.33 & 11.55 \\
\hline V4 & 0 & 0 & 80 & $*$ & 30 & $*$ & 0 & $*$ & 20 & 0 \\
\hline V5 & 50 & 70.7 & 50 & $*$ & 100 & $*$ & 80 & $*$ & 0 & 0 \\
\hline V6 & 65 & 21.2 & 0 & $*$ & 100 & $*$ & 100 & $*$ & 33.3 & 57.7 \\
\hline V7 & 90 & 14.1 & 0 & $*$ & 100 & $*$ & 80 & $*$ & 33.3 & 57.7 \\
\hline V8 & 100 & 0 & 0 & $*$ & 100 & $*$ & 0 & $*$ & 66.7 & 57.7 \\
\hline V9 & 90 & 14.1 & 100 & $*$ & 50 & $*$ & 100 & $*$ & 100 & 0 \\
\hline V10 & 100 & 0 & 80 & $*$ & 50 & $*$ & 100 & $*$ & 66.7 & 57.7 \\
\hline V11 & 40 & 56.6 & 50 & $*$ & 80 & $*$ & 100 & $*$ & 66.7 & 57.7 \\
\hline V12 & 100 & 0 & 0 & $*$ & 20 & $*$ & 0 & $*$ & 66.7 & 57.7 \\
\hline V13 & 43.8 & 61.9 & 802.8 & $*$ & 0 & $*$ & 501.52 & $*$ & 387 & 347 \\
\hline V14 & 0.93 & 1.315 & 92.917 & $*$ & 0 & $*$ & 31.74 & $*$ & 41.3 & 58.7 \\
\hline V15 & 0.0488 & 0.069 & 1.4054 & $*$ & 0 & $*$ & 0.94881 & $*$ & 0.4569 & 0.1314 \\
\hline V16 & 0.13 & 0.0283 & 0.18 & $*$ & 0 & $*$ & 0.43 & $*$ & 0 & 0 \\
\hline
\end{tabular}


Table 8: Environmental indicators per island, for Anafi, Antiparos, Donousa and Iraklia.

\begin{tabular}{|l|l|l|l|l|l|l|l|l|l|}
\hline & \multicolumn{2}{l}{ ANAFI } & \multicolumn{2}{l}{ ANTIPAROS } & \multicolumn{2}{l|}{ DONOUSA } & \multicolumn{2}{l|}{ IRAKLIA } \\
\hline & Mean & StDev & Mean & StDev & Mean & StDev & Mean & StDev \\
\hline V1 & 0 & $*$ & 0 & $*$ & 0 & $*$ & 0 & $*$ \\
\hline V2 & 100 & $*$ & 0 & $*$ & 100 & $*$ & 100 & $*$ \\
\hline V3 & 80 & $*$ & 80 & $*$ & 100 & $*$ & 100 & $*$ \\
\hline V4 & 80 & $*$ & 30 & $*$ & 0 & $*$ & 0 & $*$ \\
\hline V5 & 80 & $*$ & 0 & $*$ & 100 & $*$ & 100 & $*$ \\
\hline V6 & 100 & $*$ & 0 & $*$ & 100 & $*$ & 100 & $*$ \\
\hline V7 & 100 & $*$ & 0 & $*$ & 0 & $*$ & 0 & $*$ \\
\hline V8 & 100 & $*$ & 100 & $*$ & 100 & $*$ & 100 & $*$ \\
\hline V9 & 100 & $*$ & 100 & $*$ & 100 & $*$ & 100 & $*$ \\
\hline V10 & 100 & $*$ & 100 & $*$ & 50 & $*$ & 100 & $*$ \\
\hline V11 & 20 & $*$ & 80 & $*$ & 100 & $*$ & 100 & $*$ \\
\hline V12 & 0 & $*$ & 0 & $*$ & 100 & $*$ & 100 & $*$ \\
\hline V13 & 133.83 & $*$ & 320.96 & $*$ & 250 & $*$ & 153.33 & $*$ \\
\hline V14 & 19.053 & $*$ & 67.328 & $*$ & 38.462 & $*$ & 13.068 & $*$ \\
\hline V15 & 2.652 & $*$ & 2.2594 & $*$ & 3.0675 & $*$ & 1.5232 & $*$ \\
\hline V16 & 0 & $*$ & 0 & $*$ & 0 & $*$ & 0 & $*$ \\
\hline
\end{tabular}

Table 9: Environmental indicators per island, for Kimolos, Koufonisi, Sikinos, Schinousa and Folegandros.

\begin{tabular}{|l|l|l|l|l|l|l|l|l|l|l|}
\hline & \multicolumn{2}{l}{ KIMOLOS } & \multicolumn{2}{l|}{ KOUFONISI } & \multicolumn{2}{l|}{ SIKINOS } & \multicolumn{2}{l}{ SCHINOUSA } & \multicolumn{2}{l|}{ FOLEGANDROS } \\
\hline & Mean & StDev & Mean & StDev & Mean & StDev & Mean & StDev & Mean & StDev \\
\hline V1 & 0 & $*$ & 100 & & 0 & $*$ & 0 & $*$ & 0 & $*$ \\
\hline V2 & 0 & $*$ & 100 & $*$ & 0 & $*$ & 50 & $*$ & 50 & $*$ \\
\hline V3 & 100 & $*$ & 80 & $*$ & 100 & $*$ & 100 & $*$ & 80 & $*$ \\
\hline V4 & 80 & $*$ & 0 & $*$ & 50 & $*$ & 0 & $*$ & 80 & $*$ \\
\hline V5 & 0 & $*$ & 0 & $*$ & 100 & $*$ & 0 & $*$ & 50 & $*$ \\
\hline V6 & 100 & $*$ & 100 & $*$ & 100 & $*$ & 100 & $*$ & 100 & $*$ \\
\hline V7 & 0 & $*$ & 0 & $*$ & 0 & $*$ & 0 & $*$ & 100 & $*$ \\
\hline V8 & 0 & $*$ & 100 & $*$ & 0 & $*$ & 100 & $*$ & 0 & $*$ \\
\hline V9 & 100 & $*$ & 100 & $*$ & 100 & $*$ & 100 & $*$ & 100 & $*$ \\
\hline V10 & 100 & $*$ & 20 & $*$ & 100 & $*$ & 20 & $*$ & 100 & $*$ \\
\hline V11 & 100 & $*$ & 20 & $*$ & 100 & $*$ & 50 & $*$ & 100 & $*$ \\
\hline V12 & 0 & $*$ & 100 & $*$ & 0 & $*$ & 0 & $*$ & 100 & $*$ \\
\hline V13 & 30.4 & $*$ & 880.5 & $*$ & 216.22 & $*$ & 123.06 & $*$ & 1329.2 & $*$ \\
\hline V14 & 6.3333 & $*$ & 475.95 & $*$ & 5.8537 & $*$ & 55.375 & $*$ & 81 & $*$ \\
\hline V15 & 0.29649 & $*$ & 5.0314 & $*$ & 1.0084 & $*$ & 2.1505 & $*$ & 3.8861 & $*$ \\
\hline V16 & 0 & $*$ & 0 & $*$ & 0 & $*$ & 0 & $*$ & 0 & $*$ \\
\hline
\end{tabular}


According to the results for indicator V3 "Protection from noise nuisance", a serious noise problem is present in mass tourism districts such as Paros and Thira.

Regarding fresh water consumption, indicators V7 and V8, demand increases during the summer months in all the islands. Some islands have to deal with incidents of infiltration of sea water into drinking water sources.

The Greek municipalities do not manage their destination needs with specialized management schemes. Only some islands implement specialised destination management know-how, using scientists or specialized companies.

The indicators V13, "Beds per km of beach", and V14, "Beds per square km", indicate that the islands of Syros, Thira, Mykonos, Paros, Sifnos, and Koufonisi experience serious coastal pressures, with more than 400 beds per kilometre of beach; and Syros, Amorgos, Mykonos, Thira (Santorini), and Koufonisi have more than 100 beds per square kilometre. Amorgos, Mykonos, Anafi, Donousa, Iraklia, Paros, Koufonis, Mykonos, Schinousa and Folegadros have more than 2 beds per inhabitant, as per indicator V15 "beds per inhabitants". In the 24 islands of the Cyclades, only 10 have blue flags.

Paros, Antiparos and Syros have serious pressures from illegal buildings practices, indicator V2.

Urban waste management (solid and liquid) on the islands is characterized by a lack of efficiency regarding the waste treatment in the cities, which is very pronounced in the city of Tinos and the city of Naxos, indicator V1. The population of these cities is 6,000 inhabitants each. That causes serious problems for the tourism industry of these places. Moreover, it is noteworthy that other smaller settlements do not even have a complete urban waste collection network.

In general, the number of indicators presented in this research and their variations indicated among the Cyclades Islands do not lead directly to any specific conclusion on the carrying capacity issues. The indicators are mostly presenting a measurement outcome that the local communities have to examine thoroughly, in order to set limitations and decide policies towards advancing future tourism development in a sustainable way. Local and regional stakeholders have to understand the potential threats if some of these measured indicators show a significant change in the future, due to uncontrolled tourism growth. These indicators are the main tools meant to help specify the meaning of tourist carrying capacity for the region and each one of those islands, something that will allow them to have strategic decision-making regarding their tourism development, and of course to create and implement policies to maintain the outcome of those indicators on a desired level.

\section{DISCUSSION}

Tourism causes enormous stress on local land use, and may lead to soil erosion, increased pollution, natural habitat loss, and place more pressure on endangered species. These effects may gradually destroy the environmental resources on which tourism depends. Case studies, carried out in the capital of Samos island, confirm the serious impact of development without planning and without a comprehensive environmental policy. In Samos, the local authorities are currently focusing on ways to improve the situation, by creating the necessary environmental infrastructure.

Sustainable tourism must be developed in the Greek islands, as well as in all other destinations [18]. This will ensure that saturated areas may progress towards developing quality and alternative tourist services. Areas that are not yet developed should not necessarily strive to develop in the same way or to the same extent as the existing major tourist destinations, but they should, at the early stages of their development, plan ahead by making sure that policy development and implementation go hand in hand, leading to a truly 
competitive and environmentally sound business [19]. The target should be a combination model of typical and alternative tourist development that takes into account the local community's needs and the uniqueness of the Cycladic environment. Despite their relatively small area, all these islands have an exceptionally rich natural environment, with a great variety of landscapes, natural habitats, flora and fauna [20]. Therefore, tourist development must aim at a combination of the classical tourist model with alternative tourist activities, that make the most of the uniqueness of both the natural and human environment of the Cyclades. Such activities could include:

1. Ecotourism: Footpaths, wine roads and climbing;

2. Diving;

3. Archaeological trekking;

4. Museums;

5. Traditional villages;

6. Cultural tourism related to traditional or religious customs; and

7. Local festivals and exhibitions used as cultural attractions in order to extend the tourist season [21].

With this in mind, it should be emphasised that the tourism industry must be extended by supporting winter charter flights. Finally, there is a need to complete the construction of urban sewage and waste treatment plants that are still pending, including the appropriate network for garbage handling (urban garbage treatment and olive oil press residuals management, as well), and to ensure both the implementation of urban planning guidelines and the policing of illegal building activity, especially near coastal areas.

Greek municipalities need to implement tourist destination management schemes, making use of specialists that currently, only a few islands employ. It is obvious that island destinations have to focus on their traditional and authentic characteristics, in order to be able to implement a strategy for sustainable development. They need to have an integrated approach to their tourism resources, in order to optimize the use of the competitive advantages for their promotion. These schemes need to get the whole community on board and must involve all local stakeholders, both in its design and in its implementation.

In future research related with carrying capacity for such island regions, it is essential to make sure that each island destination is able first to understand which environmental and sociocultural elements are unique and vital for their competitiveness, and then that they have the right systems developed to measure and evaluate the status of these important elements with the use of selected indicators [22], [23]. Additionally, stakeholders may need to understand the importance of the carrying capacity issue for their current and future wellbeing, in order to share a common vision on their way to a strategic plan for their sustainable tourism development, through the assessment of carrying capacity [24], [25].

\section{ACKNOWLEDGEMENTS}

This study is dedicated to the memory of our academic colleague Professor Carlos Brebbia, whose contributions to the WIT conferences from 2002 to 2017 were invaluable. We all feel privileged to have had the honour of knowing him and for the time he spent with us talking about the philosophy of science. This study was carried out and partially supported by the Research Centre of the University of Piraeus. We would like to thank the economists Tselou, D. and Frangopoulos, D. 


\section{REFERENCES}

[1] Briassouls, H., Policy and practice, sustainable development and its indicators: Through a (planner's) glass darkly. Journal of Environmental Planning and Management, 44(3), pp. 409-427, 2001.

[2] Farrell, B. \& Runyan, D., Ecology and Tourism, Annals of Tourism Research, 18(1), pp. 26-40, 1991.

[3] Needham, M. \& Szuster, B., Situational influences on normative evaluations of coastal tourism and recreation management strategies in Hawaii. Tourism Management, 32, pp. 732-740, 2011.

[4] Charlier, R. \& De Meyer, C., Tourism and the coastal zone: The case of Belgium. Ocean and Coastal Management, 18, pp. 231-240, 1992.

[5] Prokopiou, D.G., Tselentis, B.S., Bousbouras, D. \& Toanoglou, M., Carrying capacity assessment in tourism: The case of Dodecanese archipelago. The Ravage of the Planet, First International Conference on the Management of Natural Resources, Sustainable Development and Ecological Hazards, Bariloche, Argentina, Wessex Institute of Technology, UK, University of Siena, 2006.

[6] Jarmozy, U., Sustainable tourism development: ingenuity in marketing strategy. Sustainable Tourism III International Conference, Malta, Wessex Institute of Technology, UK, The Compulence University, Spain, 2008.

[7] Ntibanyurwa, A., Tourism as a factor of development. Sustainable Tourism II International Conference, Bologna, Italy, Wessex institute of Technology, UK, The Compulence University, Spain, 2006.

[8] Priestley, G.K., Edwards, J.A. \& Coccossis, H., Sustainable Tourism - European Experiences. Cab International, p. ix, 1996.

[9] Prokopiou, D.G., Tselentis, B.S., Bousbouras. D. \& Toanoglou, M., Sustainability indicators and their role to destinations' strategic development. Sustainable Tourism as a Factor of Local Development Conference, Monza, Italy, 2008.

[10] Elkington, J., Accounting for the triple bottom line. Measuring Business Excellence, 2(3), pp. 18-22, 1998. DOI: https://doi.org/10.1108/eb025539.

[11] Losano-Oyola, M., Janvier-Blancas, F., Gonzalez, R. \& Caballero, M., Sustainable tourism indicators as planning tools in cultural destinations. Ecological Indicators, 18, pp. 659-675, 2012.

[12] Hadjibiros, K., Aravantinou, M. \& Lapsidou, C., Organization and evaluation of a sustainable island network. International Journal of Sustainable Development and Planning, 6(1), pp. 13-20, 2011.

[13] Blancas, F.J., Gonzalez, M., Lozano-Oyola, M. \& Perez, F., The assessment of sustainable tourism: Application to Spanish coastal destinations. International Journal Ecological Indicators, 10, 2010.

[14] Petrosillo, I., De Marco, A., Botta, S. \& Comoglio, C., EMAS in local authorities who suitable indicators in adopting environmental management systems. Ecological Indicators, 10, 2011.

[15] Navaro Jurado, E. et al., Carrying capacity for tourist destinations. Methodology for the Creation for Synthetic Indicators Applied in Costal Area, Tourism Management, 33, pp. 1337-1346, 2012.

[16] Prokopiou, D.G., Nikolaidou, H, Mavridoglou, G, Manologlou, S \& Tselentis, B.S., Sustainable tourism and destination management: the Greek island of Poros. 9th Conference on Sustainable Development \& Planning, 27-29 June, 2017 Bristol, UK, WIT Transactions on Ecology and the Environment, 226, WIT Press: Southampton and Boston, 2017. 
[17] Prokopiou, D.G., Tselentis, B.S. \& Mavridoglou, G., Carrying capacity as a tool to design tourism policy: Case study for the islands of Dodecanese. Seventh International Conference on Sustainable Tourism, Madrid and Valencia, Spain, 2016.

[18] Prokopiou, D.G., Tselentis, B.S., Bousbouras, D. \& Toanoglou, M., Carrying capacity assessment for the Greek islands of Kalymnos, Kos and Rhodes. Sustainable Tourism II International Conference, Bologna, Italy, Wessex Institute of Technology, UK, The Compulence University, Spain, 2006.

[19] Prokopiou, D.G., Tselentis, B.S., Bousbouras, D. \& Toanoglou, M., Environmental impacts caused by the tourist industry in Elafonisos Island and the Neapoli district, Greece. ECOSUD 2007, Sixth International Conference on Ecosystems and Sustainable Development, Wessex Institute of Technology, UK, The University of Coimbra, Portugal, 2007.

[20] Prokopiou, D.G., MBA Dissertation: Regional Investment Study for Kos and Rhodes Islands, University of Piraeus, 2005.

[21] Tselentis, B.S. \& Prokopiou, D.G., Tourism carrying capacity assessment and the environment: the case of Crete. International Conference on Ecosystems and Sustainable Development, Alicante, Spain, 2011.

[22] Ma, P., Ye, G., Peng, X., Liu, J., Qi, J. \& Jia, S., Development of an index system for evaluation of ecological carrying capacity of marine ecosystems. Ocean \& Coastal Management, 144, pp. 23-30, 2017.

[23] Pamungkas, A., Sulistyono, A., Kukinul, V. \& Siswanto V., Poteran carrying capacity for small island development. Procedia - Social and Behavioral Sciences, 227, pp. 761-769, 2016.

[24] Jurado, N. et al., Carrying capacity assessment for tourist destinations. Methodology for the creation of synthetic indicators applied in a coastal area. Tourism Management, 33, pp. 1337-1346.

[25] Zacarias, D., Williams, A. \& Newton, A., Recreation carrying capacity estimations to support beach management at Praia de Faro, Portugal. Applied Geography, 31(3), pp. 1075-1081. 